\title{
Sydney Brenner \\ (1927-2019)
}

Mischievous steward of molecular biology's golden age.

S ydney Brenner was one of the first to view James Watson and Francis Crick's double helix model of DNA in April 1953. The 26-year-old biologist from South Africa was then a graduate student at the University of Oxford, UK. So enthralled was he by the insights from the structure that he determined on the spot to devote his life to understanding genes.

Iconoclastic and provocative, he became one of the leading biologists of the twentieth century. Brenner shared in the 2002 Nobel Prize in Physiology or Medicine for deciphering the genetics of programmed cell death and animal development, including how the nervous system forms. He was at the forefront of the 1975 Asilomar meeting to discuss the appropriate use of emerging abilities to alter DNA, was a key proponent of the Human Genome Project, and much more. He died on 5 April.

Brenner was born in 1927 in Germiston, South Africa to poor immigrant parents. Bored by school, he preferred to read books borrowed (sometimes permanently) from the public library, or to dabble with a selfassembled chemistry set. His extraordinary intellect - he was reading newspapers by the age of four - did not go unnoticed. His teachers secured an award from the town council to send him to medical school.

Brenner entered the University of the Witwatersrand in Johannesburg at the age of 15 (alongside Aaron Klug, another sciencegiant-in-training). Here, certain faculty members, notably the anatomist Raymond Dart, and fellow research-oriented medical students enriched his interest in science. On finishing his six-year course, his youth legally precluded him from practising medicine, so he devoted two years to learning cell biology at the bench. His passion for research was such that he rarely set foot on the wards - and he initially failed his final examination in internal medicine.

In 1952 Brenner won a scholarship to the Department of Physical Chemistry at Oxford. His adviser, Cyril Hinshelwood, wanted to pursue the idea that the environment altered observable characteristics of bacteria. Brenner tried to convince him of the role of genetic mutation. Two years later, with doctorate in hand, Brenner spent the summer of 1954 in the United States visiting labs, including Cold Spring Harbor in New York state. Here he caught up with Watson and Crick again.

Impressed, Crick recruited the young

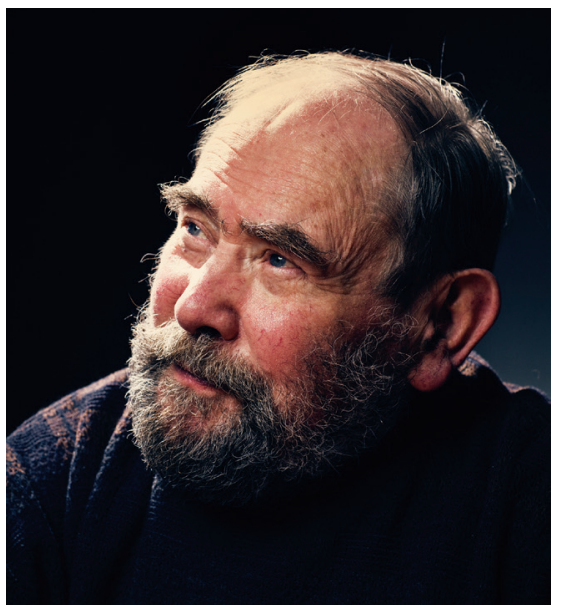

South African to the University of Cambridge, UK, in 1956. In the early 1960s, using just bacteria and bacteriophages, Crick and Brenner deciphered many of the essentials of gene function in a breathtaking series of studies.

Brenner had proved theoretically in the mid-1950s that the genetic code is 'non-overlapping' - each nucleotide is part of only one triplet (three nucleotides specify each amino acid in a protein) and successive 'triplet codons' are read in order. In 1961, Brenner and Crick confirmed this in the lab. The same year, Brenner, with François Jacob and Matthew Meselson, published their demonstration of the existence of messenger RNA. Over the next two years, often with Crick, Brenner showed how the synthesis of proteins encoded by DNA sequences is terminated.

This intellectual partnership dissolved when Brenner began to focus on whole organisms in the mid-1960s. He finally alighted on Caenorhabditis elegans. Studies of this tiny worm in Brenner's arm of the legendary Laboratory of Molecular Biology (LMB) in Cambridge led to the Nobel for Brenner, Robert Horvitz and John Sulston.

And his contributions went well beyond the lab. In 1975, with Paul Berg and others, he organized a meeting at Asilomar, California, to draft a position paper on the United States' use of recombinant DNA technology — introducing genes from one species into another, usually bacteria. Brenner was influential in persuading attendees to treat ethical and societal concerns seriously. He stressed the importance of thoughtful guidelines for deploying the technology to avoid overly restrictive regulation.
He served as director of the LMB for about a decade. Despite describing the experience as the biggest mistake in his life, he took the lab (with its stable of Nobel laureates and distinguished staff) to unprecedented prominence. In 1986, he moved to a new Medical Research Council (MRC) unit of molecular genetics at the city's Addenbrooke's Hospital, and began work in the emerging discipline of evolutionary genomics. Brenner also orchestrated Britain's involvement in the Human Genome Project in the early 1990s.

From the late 1980s, Brenner steered the development of biomedical research in Singapore. Here he masterminded Biopolis, a spectacular conglomerate of chrome and glass buildings dedicated to biomedical research. He also helped to guide the Janelia Farm campus of the Howard Hughes Medical Institute in Ashburn, Virginia, and to restructure molecular biology in Japan.

Brenner dazzled, amused and sometimes offended audiences with his humour, irony and disdain of authority and dogma - prompting someone to describe him as "one of biology's mischievous children; the witty trickster who delights in stirring things up." His popular columns in Current Biology (titled 'Loose Ends' and, later, 'False Starts') in the mid-1990s led some seminar hosts to introduce him as Uncle Syd, a pen name he ultimately adopted.

Sydney was aware of the debt he owed to being in the right place at the right time. He attributed his successes to having to learn scientific independence in a remote part of the world, with few role models and even fewer mentors. He recounted the importance of arriving in Oxford with few scientific biases, and leaving with the conviction that seeing the double helix model one chilly April morning would be a defining moment in his life.

The Brenner laboratories (he often operated more than one) spawned a generation of outstanding protégés, including five Nobel laureates. Those who dedicated their careers to understanding the workings of C. elegans now number in the thousands. Science will be considerably poorer without Sydney. But his name will live forever in the annals of biology.

Errol Friedberg is an emeritus professor at the University of Texas Southwestern Medical Center at Dallas, USA, and author of Sydney Brenner: A Biography.

e-mail:errol.friedberg@utsouthwestern.edu 